\title{
TECHNICAL FEASIBILITY OF DECEIT WHILE A VEHICLE IS WEIGHED IN MOTION WITH A VERY LOW SPEED
}

\author{
Zbigniew Lozia \\ Faculty of Transport, Warsaw University of Technology, Warsaw, Poland \\ *E-mail of corresponding author: zbigniew.lozia@pw.edu.pl
}

\begin{abstract}
Resume
The study concerns the problem of overloading the vehicles driven on public roads. The gross vehicle mass and individual axle loads are limited by legal regulations. However, a tricking method, applicable to most popular designs of motor vehicles and multiaxial tractor-semitrailer units, has been shown that the weighing inspectors, even if provided with precise scales, may be deceived without any interference in the scale operation. In such a method, the current vehicle state may be changed by modifying the stiffness of individual pneumatic suspension springs, which is now technically feasible. The author used two authorial vehicle models and a simulation program. Calculation results obtained for a four-axle motor vehicle and a five-axle tractor-semitrailer unit, taken as an example, have been demonstrated. They show that a deceit is possible when a vehicle is weighed in motion with a very low speed.
\end{abstract}

Available online: https://doi.org/10.26552/com.C.2021.1.D1-D14

\author{
Article info \\ Received 6 March 2020 \\ Accepted 6 June 2020 \\ Online 26 October 2020

\section{Keywords:} \\ vehicle weighing, \\ WIM, \\ Weigh-In-Motion, \\ road surface load, \\ vehicle overload, \\ deceit at vehicle weighing
}

ISSN $1335-4205$ (print version) ISSN 2585-7878 (online version)

\section{Introduction}

The motor transport of passengers and goods plays a key role in economies of most countries in Europe and other continents. However, the bearing capacity of land roads is not unlimited. Therefore, the legal regulations have been adopted to restrict the acceptable gross vehicle mass and the normal forces exerted by wheels of individual vehicle axles on the road surface [1]. The limits thus imposed depend on specific road class (traffic service level), vehicle type, position of a specific axle in the suspension system structure and vehicle's running gear. Transportation companies and their drivers try to make use of vehicle's load capacity to the maximum possible extent. They reduce the "idle mileage" to the minimum, which is a reasonable trend. Simultaneously, however, it happens quite often that they overload (unconsciously or intentionally) their vehicles by exceeding the acceptable gross mass of the vehicle or the tractor-semitrailer unit or by incorrectly arranging the cargo. In both cases, that causes the axle loads to exceed the acceptable limits. As a consequence, the overloaded road surface undergoes more intensive wear. According to [2], the $10 \%$ exceedance of the acceptable limit of the road surface load may raise the road-destroying effect by $45 \%$. Another negative effect of the vehicle overloading is increased traffic accident hazard arising from higher loads on vehicle's running gear and on its braking and steering systems. In Poland, like in many other (especially East European) countries, there are still shortages in the network of modern roads with high load capacity; as a consequence, the traffic of heavy vehicles takes place in a considerable part on the lower-class roads. It also happens that drivers, trying to avoid the payment of a toll, choose local highways and the progressing deterioration of such roads constitutes a serious problem for local authorities. The Minister of Infrastructure and Development and the Road Transport Inspection (ITD) in Poland receive many related questions, appeals and requests, which sometimes have the form of parliamentary questions [3] and are formulated in result of analyses carried out by institutions subordinated to legislative authorities [4]. The said Road Transport Inspection (ITD) has adequate equipment necessary to carry out continuous and periodic inspections of vehicle loading.

This paper's aim is to present the problem of a possibility of the ITD inspectors being cheated when measuring the vehicle axle loads and even if instruments of the highest possible accuracy are used at that. Thus, apart from the problem exploration aspect, the purpose of this study is to direct inspectors' attention to the possible hazard of deceit.

\section{Systems for weighing vehicles in motion}

The systems for weighing vehicles in motion have been developed as a result of many years of research, experiments and construction of measuring equipment 
and as an effect of experience gained from multiannual operation of such devices in the USA and in many European countries. They were first built in the USA in 1951 [5]. In Europe, the earliest one was made in the UK in 1978 [6] and intensive research and engineering works aimed at construction of systems intended to determine the weight of a vehicle in motion, referred to as weigh-in-motion (WIM) systems, have been done since 1990s. In publications [2, 6-9], such projects as COST323 (1993-1999), WAVE (1996-1999), TOP TRAIL (2000-2002), REMOVE (2004-2006) and FiWi (2007-2009) have been mentioned. The researchers and scientists involved in exploring such issues meet together at cyclic conferences named ICWIMi (the most recent one, ICWIM8, was held in Prague in May 2019).

Publication [6] presents division of the WIM systems into on-board and road WIM systems and the latter are divided into non-invasive (seismic) and embedded systems. The embedded systems may use a bridge structure as the measuring device (they are referred to as BridgeWIM or B-WIM systems) or may be installed in or under the pavement (Pavement WIM systems), which in turn are divided into Low Speed (LS-WIM) and High Speed (HS-WIM) systems operating at vehicle speeds of up to $10 \mathrm{~km} \cdot \mathrm{h}^{-1}$ and higher (even up to $80-120 \mathrm{~km} \cdot \mathrm{h}^{-1}$ ), respectively. The latter may be made as one- or two-sensor devices or as multi-sensor (Multi-Sensor WIM or MS-WIM) systems. A matter of critical importance here is the measurement accuracy, specified as about $2 \%$ for the LS-WIM systems and $7-20 \%$ for the HS-WIM ones. For the most modern MS-WIM systems, where even as many as 16 sensors may be employed, the accuracy is $2 \%$ [6].

To determine vehicle weights, static (or quasi-static) scales with an accuracy of the order of $\pm 1 \%$ [10] are also used (some manufacturers even declare an accuracy of $0.03 \%[11]$ ). They are made as weighbridges (or platform scales) for vehicles as a whole [10-19] and stationary or mobile scales for determining the loads on individual vehicle wheels or on two wheels of the same vehicle axle $[12,16,20-21]$. The measurement results obtained from this equipment may provide grounds for imposing penalties for overloading of vehicles in relation to the requirements specified in the applicable normative document [1]. The measurements in this case take more time than required when other equipment is used and the vehicle must pull in. Therefore, such measurements are carried out when a suspicion of a vehicle overload is indicated by the road WIM system (chiefly an HS-WIM system). Therefore, the HS-WIM systems are treated as intended for in-motion preselection of overloaded vehicles [2, 5-9, 22-23].

In the USA, the ASTM E1318 standard is in force [5], according to which the WIM systems have been divided into types I, II, III and IV. Type I and Type II systems are used for collecting traffic data (at vehicle speeds of 10-80 mi.h ${ }^{-1}$ ). For Type III systems (10-80 mi.h-1 $)$, requirements corresponding to the European pre-selection systems (HS-WIM) have been formulated. Type IV is also mentioned, although not approved yet for use in the USA, but built to enforce the vehicle loading regulations (suitable for vehicle speeds of 2-10 mi. $\left.\mathrm{h}^{-1}\right)$.

Since 2014, a nationwide WIM network has been under construction in Poland. By 2015, 300 stations to weigh preselected vehicles were to be built, according to GDDKiA (General Directorate for National Roads and Motorways in Poland) [2]. The WIM network administered by ITD (Road Transport Inspection) is provided with mobile systems, i.e. scales for determining the loads on individual vehicle wheels or on two wheels of the same vehicle axle $[12,16$, 20-21].

\section{Essence of the feasible method of deceiving when a vehicle is weighed in motion with a very low speed}

Figure 1 shows a schematics that explains the way how a deceit can be committed when a vehicle is weighed in motion with a very low speed. Here, a four-axle vehicle standing on a horizontal road surface, with its axles being situated symmetrically to each other, will be used as an example. The vehicle load is so arranged that the gross vehicle weight $4 \mathrm{~F}$ causes identical normal reactions $\mathrm{F}$ to act on the wheels of individual vehicle axles (see the top part of the drawing). In this example, axle scales (simultaneously measuring the load on two wheels of the same axle) is used. Thus, four $\mathrm{F}$ values are measured (with accuracies of individual scales). If the measurement, carried out for the wheels of a specific axle (marked with a red ring in the drawing) of the vehicle under test, is immediately preceded by a reduction in the stiffness of suspension springs of the said axle (caused by e.g. the vehicle driver) then the load value actually read for this axle will be lower than F. If such a fraudulent driver's action is repeated when the loads on other axles are measured, a similar effect will be obtained. The drop in the normal reaction value determined for the axle under measurement will be accompanied by growths in the values of such reactions at the axles situated nearby (where the load is not measured at that time). In consequence, the sum of the readouts will be less than $4 \mathrm{~F}$ and the measuring inspector will record a total result lower than the actual vehicle weight $(4 \mathrm{~F})$, in spite of precise stationary scales being used. Instead of reducing the stiffness of the suspension system of the axle under measurement, the suspension stiffness at the other (or neighbouring) axles may be raised to obtain a similar effect. A schematic similar to the one presented in Figure 1 may also be drawn for a multiaxial tractor-semitrailer unit.

The following questions arise:

- Can the suspension stiffness be changed during the slow vehicle motion on the measuring stand?

- Can the possible changes in the suspension stiffness at individual vehicle axles be big enough for the difference between the actual vehicle weight and the sum of individual readings to be such that the driver would avoid punishment for vehicle overloading? 

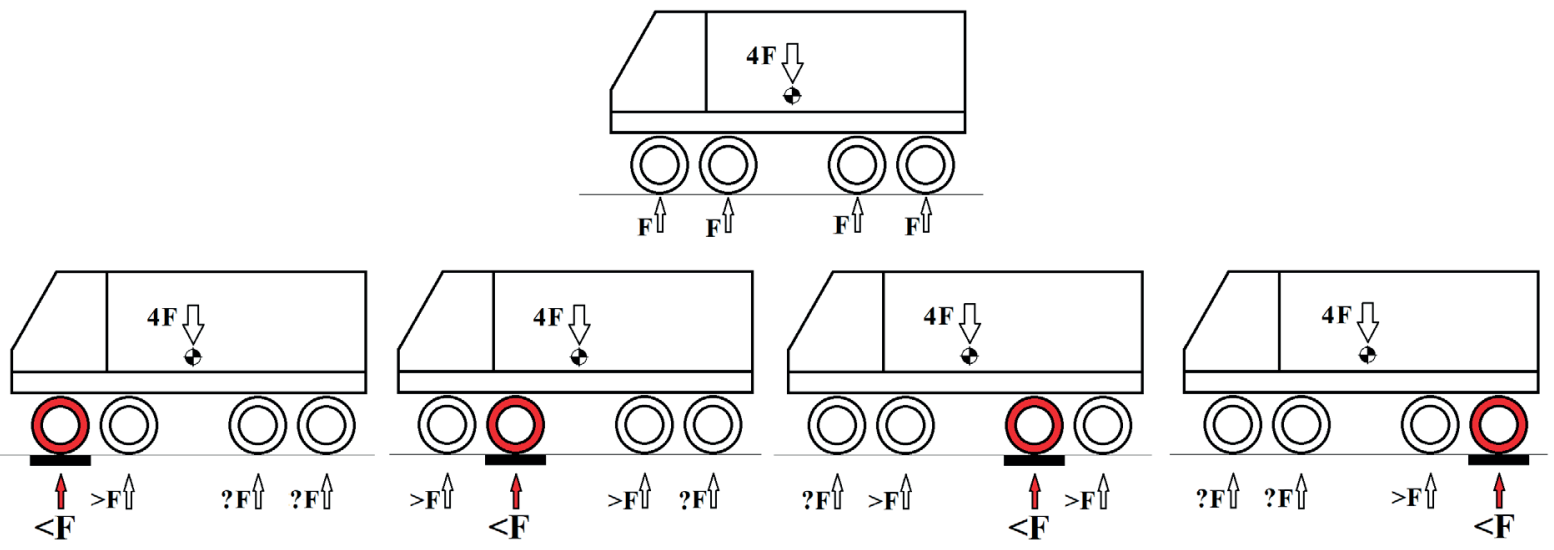

Figure 1 Schematics to explain the possibility of deceit when a vehicle is weighed in motion with a very low speed. The red rings indicate the axles where the suspension spring stiffness is temporarily reduced.

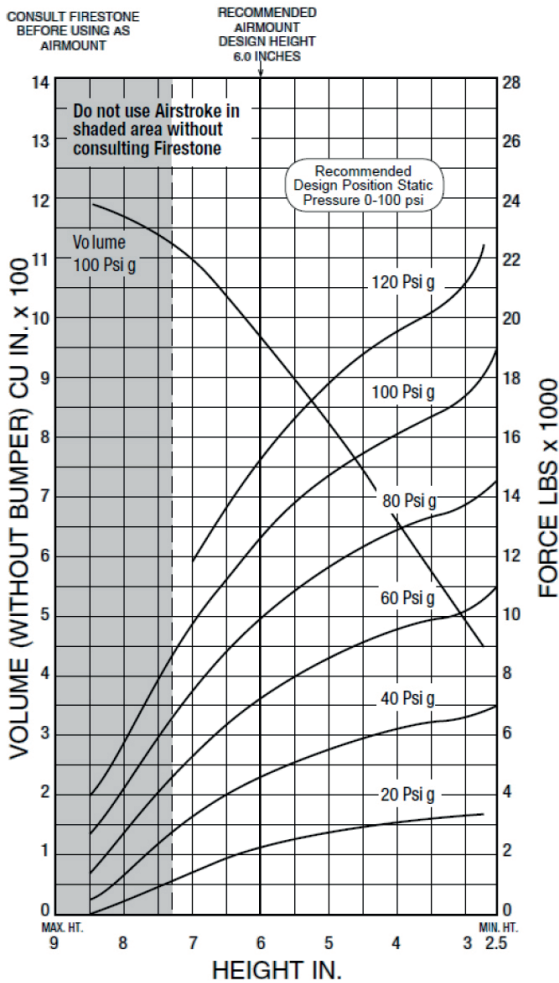

a.

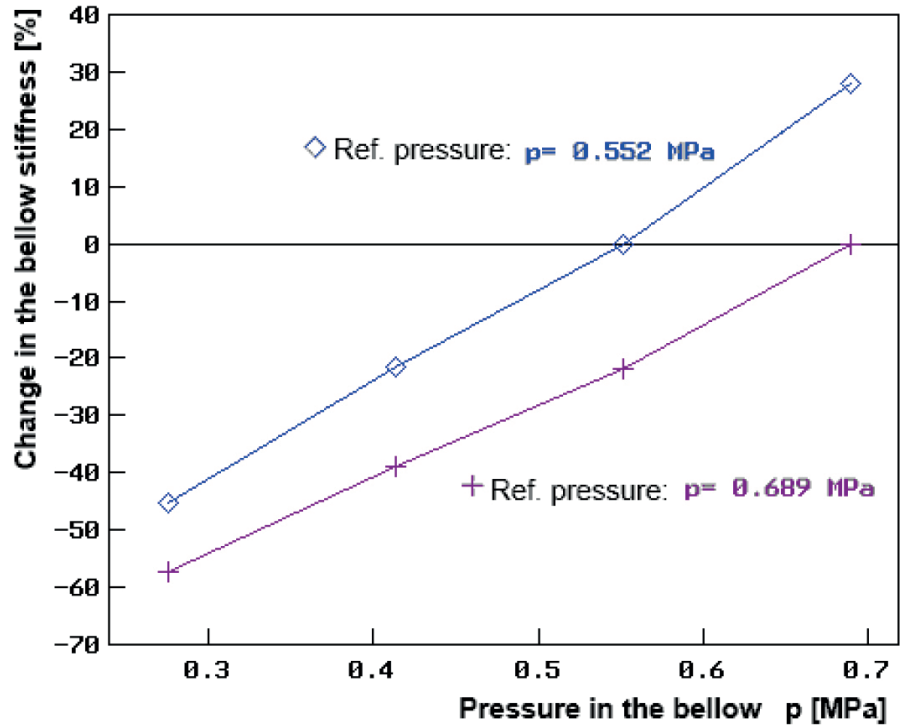

$b$.

Figure 2 a. Example characteristics of the pneumatic suspension spring (air bellow) of a motor truck: force $(l b s \times 1000=4.54 \times 1000 \mathrm{~N})$ vs current bellow height $($ in $=0.0254 \mathrm{~m})$ for various constant values of bellow inflation pressure (above atmospheric, e.g. 100 psig=0.689 MPa) [25], b. Relative changes in the air bellow stiffness for two different reference pressure values (0.552 MPa and 0.689 MPa in this case, as specified)

- Similar questions may be asked in the case of examining a single axle and comparing the measurement result with the legally acceptable limit.

The computer systems (LAN) and on-board diagnostic systems used in motor vehicles provide technical possibilities that the first question may be answered affirmatively.

For the "YES" answer to be given to the second question, some preconditions must be met. First, the vehicle under consideration must be provided with a suspension system with controllable stiffness, e.g. a pneumatic one.
At present, there are many vehicles with such systems [2426], especially those designed for the long-range operation, where driver's comfort and reduction of vibrations, having an impact on the cargo transported, are a matter of importance. This particularly applies to suspension systems of semitrailers (e.g. Wielton, Fruehauf, Schmitz, Kogel), as well as trucks and truck-tractors (in the latter case, not all the vehicle axles are so equipped). Even the manufacturers of the four-axle motor trucks, designed for operation in the building industry and driven on unpaved roads (e.g. Scania, Volvo, Iveco and Renault), provide selected 


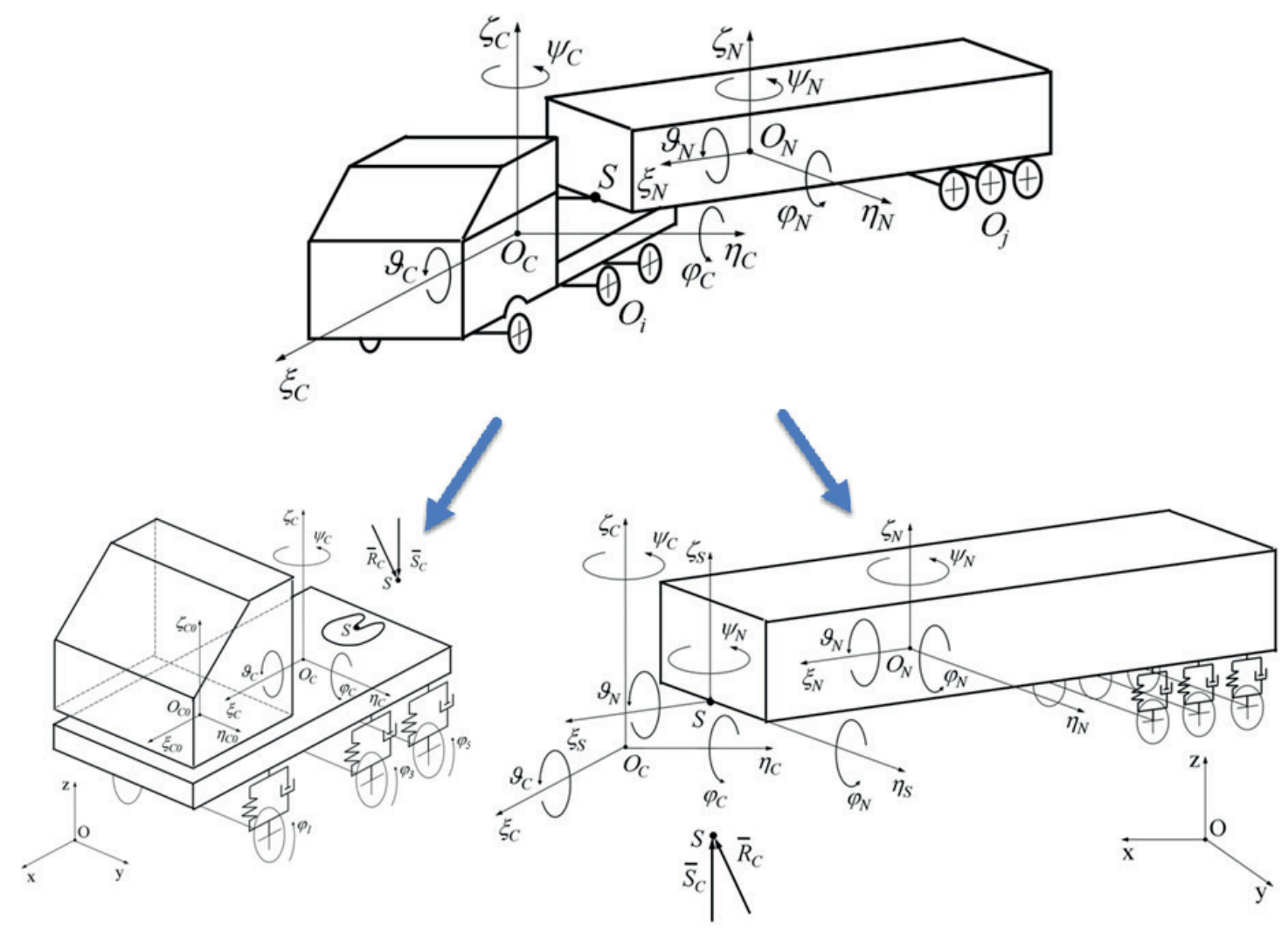

Figure 3 Model of a tractor-semitrailer unit for the simulation of the vehicle motion and dynamics, including real time simulation. 29 degrees of freedom, i.e. $x_{01}, y_{O 1}, z_{01}, \psi_{1}, \varphi_{1}, \vartheta_{1}, \zeta_{C 1}, \zeta_{C 2}, \zeta_{C 3}, \zeta_{C 4}, \varphi_{1}, \varphi_{2}, \varphi_{3}, \varphi_{4}, \psi_{N}, \varphi_{N}, \vartheta_{N}, \zeta_{N 1}, \zeta_{N 2}, \zeta_{N 3}, \zeta_{N 4}, \zeta_{N 5}, \zeta_{N 6}$, $\varphi_{7}, \varphi_{8}, \varphi_{9}, \varphi_{10}, \varphi_{11}, \varphi_{12}$. Vehicle modelled: Mercedes Actros 1841L [29]

vehicle axles with pneumatic suspension systems. Figure 2a shows an example of characteristics of the pneumatic suspension spring (air bellow) of a motor truck [25]. Figure $2 \mathrm{~b}$ illustrates relative changes in the air bellow stiffness for the two different reference pressure values ( 0.552 and 0.689 $\mathrm{MPa}$ in this case, as specified). The characteristic curves in Figure 2a represent the axial forces transmitted by the bellow as functions of the current bellow height for various inflation pressure values. As it can be seen, the slope of the curves, i.e. the suspension stiffness, increases with a growth in the bellow inflation pressure.

As an example: for the bellow height of 5 in. $(0.127$ $\mathrm{m}$ ), a pressure change from 40 psig to 100 psig (i.e. from $0.276 \mathrm{MPa}$ to $0.689 \mathrm{MPa}$ ) will cause the suspension stiffness (slope of the bellow force vs height curve) to rise more than 2.34 times (i.e. by 134\%). For the same bellow height, a reduction in the pressure from 100 psig to 40 psig (i.e. from $0.689 \mathrm{MPa}$ to $0.276 \mathrm{MPa}$ ) will cause a drop in the suspension stiffness by about $57.3 \%$. This is illustrated by the curve plotted in Figure $2 \mathrm{~b}$ for the reference bellow pressure of 100 psig (0.689 MPa). Thus, the suspension stiffness may be considerably changed by modifying the bellow inflation pressure.

Second, it should be checked by calculation whether the obtainable change in the suspension stiffness would cause a sufficient lowering of the measurement results for the cheating effect in question to be achieved. And this is exactly the objective of this study.

\section{Physical models used in the calculations}

Originally, the author planned to use his authorial MBS (Multi-Body System) models presented in [27-29]. An example model of this type, used to study dynamics of an articulated vehicle, has been shown in Figure 3. This model has 29 degrees of freedom and requires a lot of data to be predetermined, including performance curves characterizing the operation of individual vehicle component systems. Actually, the objective of the calculations carried out was to verify the hypothesis formulated in Section 3; therefore, the two simpler models were chosen, which were to be used at first for qualitative research and then for quantitative tests. The fact was taken into account that during the quasi-static measurement carried out on singlewheel scales (determining the loads on individual vehicle wheels) or on axle scales, the vehicle is moving rectilinearly with a very low speed.

Pursuant to the rule that the model adopted should chiefly represent the main vehicle characteristics in the test conditions [28, 30-31], a decision was made to reduce the complexity of structures of the models built.

Figure 4 shows the model of a four-axle motor truck moving rectilinearly with a very low speed. The model has the form of a beam representing the mass of the vehicle body solid supported by four springs that describe the elasticity of individual wheel suspension systems and pneumatic tyres (arranged in series). The masses of vehicle 


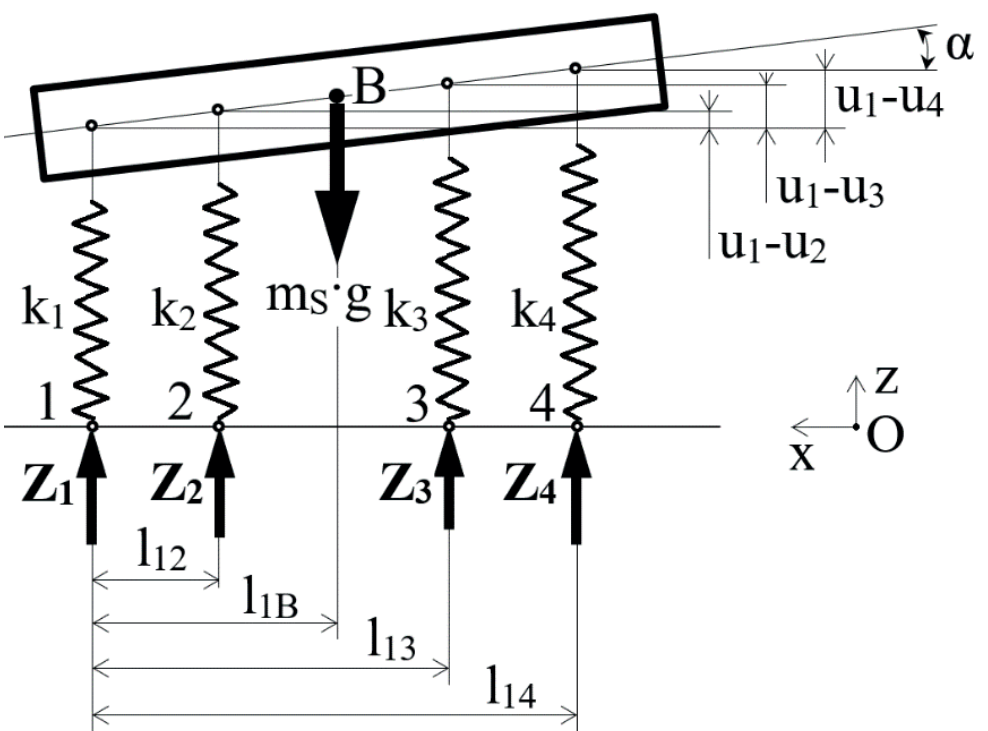

Figure 4 Model of a four-axle motor truck moving rectilinearly with a very low speed (for the meaning of the symbols used see the text)

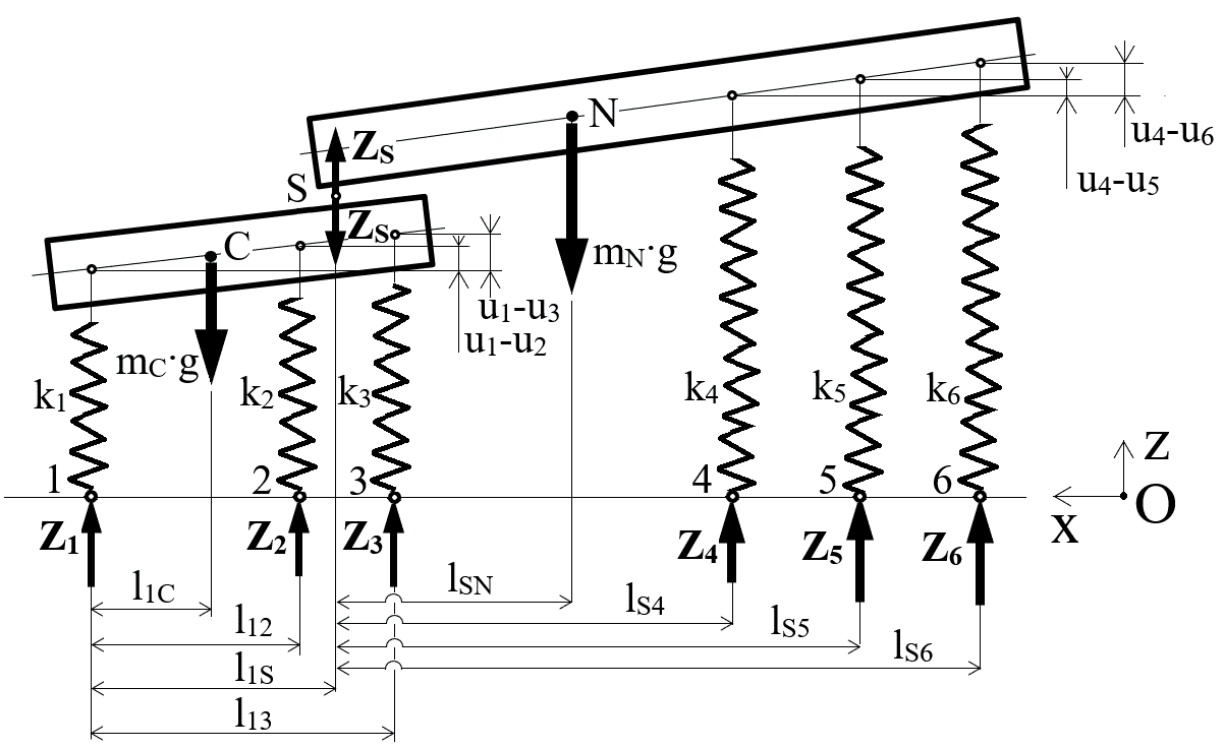

Figure 5 Model of a three-axle truck-tractor with a three-axle semitrailer moving rectilinearly with a very low speed (for the meaning of the symbols used see the text)

wheels and axles and the propulsion forces have been ignored. In the model so designed, point $\mathrm{B}$ represents the centre of a vehicle mass; $\mathrm{m}_{\mathrm{S}}[\mathrm{kg}]$ is vehicle mass; $\mathrm{g}=9.81$ $\mathrm{m} . \mathrm{s}^{-2}$ is acceleration of gravity; numerals $\mathrm{i}=1,2,3,4$ denote tyre-road contact points; $\mathrm{Z}_{\mathrm{i}}[\mathrm{N}]$ is normal reaction at the $\mathrm{i}^{\text {th }}$ tyre-road contact point (equal to the load on the $\mathrm{i}^{\text {th }}$ axle); $\mathrm{k}$ $\left[\mathrm{N} . \mathrm{m}^{-1}\right]$ is resultant stiffness of the suspension system and tyres of the $i^{\text {th }}$ axle; $l_{i j}[\mathrm{~m}]$ is a horizontal distance between point "i" and point " $\mathrm{j}$ " (here, $\mathrm{i}=1$ and $\mathrm{j}=2, \mathrm{~B}, 3,4) ; \mathrm{u}_{\mathrm{i}}[\mathrm{m}]$ is deflection of the suspension system of the $\mathrm{i}^{\text {th }}$ axle (here, $\mathrm{i}=$ $1,2,3,4) ; \alpha[\mathrm{rad}]$ is a pitch angle of the vehicle body solid. Oxy is the coordinate system attached to the road, where $\mathrm{Ox}$ is the horizontal axis and $\mathrm{Oz}$ is the vertical axis.

Figure 5 shows a similar model of a three-axle trucktractor with a three-axle semitrailer. Here, the two beams can be seen that represent masses of the tractor and semitrailer body solids. They are coupled to each other by a rotary joint representing the fifth-wheel joint in the tractor-semitrailer unit. The beams are supported by springs describing the elasticity of individual wheel suspension systems and pneumatic tyres (arranged in series as above). Masses of the vehicle wheels and axles and the propulsion forces have been ignored here, as well. In the model so designed, points $\mathrm{C}$ and $\mathrm{N}$ represent centres of mass of the truck-tractor and semitrailer, respectively; $\mathrm{S}$ is a centre of the rotary coupling between the truck-tractor and semitrailer (centre of the fifthwheel kingpin head, i.e. the "fifth-wheel centre"); $m_{c}[\mathrm{~kg}]$ is the truck-tractor mass; $\mathrm{m}_{\mathrm{N}}[\mathrm{kg}]$ is the semitrailer mass; $\mathrm{g}=$ $9.81 \mathrm{~m} . \mathrm{s}^{-2}$ is acceleration of gravity; numerals $\mathrm{i}=1,2,3,4,5$, 6 denote tyre-road contact points; $\mathrm{Z}_{\mathrm{k}}[\mathrm{N}]$ is normal reaction at the $\mathrm{k}^{\text {th }}$ tyre-road contact point (equal to the load on the $\mathrm{k}^{\text {th }}$ axle); $\mathrm{k}_{\mathrm{k}}\left[\mathrm{N} \cdot \mathrm{m}^{-1}\right]$ is resultant stiffness of the suspension system and tyres of the $\mathrm{k}^{\text {th }}$ axle; $\mathrm{Z}_{\mathrm{S}}[\mathrm{N}]$ is vertical reaction at the fifth-wheel centre (point $\mathrm{S}$ ); $\mathrm{l}_{\mathrm{kl}}[\mathrm{m}]$ is horizontal distance 
between point "k" and point "l" (here, $\mathrm{k}=1, \mathrm{~S}$; and $\mathrm{l}=\mathrm{C}, 2$, $\mathrm{S}, \mathrm{N}, 4,5,6) ; \mathrm{u}_{\mathrm{k}}[\mathrm{m}]$ is deflection of the suspension system of the $\mathrm{k}^{\text {th }}$ axle (here, $\mathrm{k}=1,2,3,4,5,6$ ). Oxy is the coordinate system attached to the road, where $\mathrm{Ox}$ is the horizontal axis and $\mathrm{Oz}$ is the vertical axis.

\section{Mathematical models for the physical models adopted}

For the physical models illustrated in Figures 4 and 5, mathematical models have been built, which describe the state of the static equilibrium of vehicles moving rectilinearly with a constant very low speed (close to zero) on a horizontal even road surface.

\subsection{Mathematical model of a four-axle motor truck}

The following additional assumptions were adopted for the model shown in Figure 4:

- differences $u_{i}-u_{j}$ in suspension system deflections are small in comparison to the $l_{\mathrm{ij}}$ dimensions specified;

- $\quad$ suspension system deflections $\mathrm{u}_{\mathrm{i}}$ are vertical (in the $\mathrm{Oz}$ direction);

- $\quad$ pitch angle $\alpha$ of the vehicle body solid is small (up to a few degrees);

- $\quad \mathrm{Z}_{\mathrm{i}}$ reactions are non-negative.

Equations that describe the state of the static equilibrium of the vehicles moving rectilinearly, with a constant very low speed, have the form of equations of forces acting in the vertical direction $\mathrm{Oz}$, equations of the moments of forces relative to point l, tangent of the pitch angle $\alpha$ of the vehicle body solid determined from deflections of the suspension systems of axles 1, 2 and 4 and tangent of this angle determined from deflections of the suspension systems of axles 1, 3 and 4. After transformations, they take a matrix form:

$$
\mathbf{A S}_{4 \mathrm{x} 4} \times \mathbf{Z S}_{4 \times 1}=\mathbf{W P S S}_{4 \mathrm{x} 1} .
$$

The non-zero elements of the AS matrix are represented by a group of relations:

$$
\begin{aligned}
& \operatorname{AS}(1,1)=\operatorname{AS}(1,2)=\operatorname{AS}(1,3)=\operatorname{AS}(1,4)=1, \\
& \operatorname{AS}(2,2)=l_{12}, \operatorname{AS}(2,3)=\mathrm{l}_{13}, \operatorname{AS}(2,4)=1_{14}, \\
& \operatorname{AS}(3,1)=\left(l_{12}-l_{14} / \mathbf{k}_{1}, \operatorname{AS}(3,2)=\mathrm{l}_{14} / \mathbf{k}_{2}, \operatorname{AS}(3,4)=-\mathrm{l}_{12} / \mathbf{k}_{4},\right. \\
& \operatorname{AS}(4,1)=\left(l_{13}-l_{14}\right) / \mathbf{k}_{1}, \operatorname{AS}(4,3)=\mathrm{l}_{14} / \mathbf{k}_{3}, \operatorname{AS}(4,4)=-\mathrm{l}_{13} / \mathbf{k}_{4} .
\end{aligned}
$$

Vector ZS has the form in Equation (3) and vector WPSS is defined by:

$\mathbf{Z S}_{4 \times 1}=\operatorname{col}\left[\mathrm{Z}_{\mathrm{i}}\right], \mathrm{i}=1,2,3,4$.

WPSS $_{4 \times 1}=\operatorname{col}\left[\mathrm{m}_{\mathrm{S}} \times \mathrm{g}, \mathrm{m}_{\mathrm{S}} \times \mathrm{g} \times \mathrm{l}_{1 \mathrm{~B}}, 0,0\right]$.
The vector $\mathbf{Z S}$ to be found (Equation (3)), representing the normal reactions (axle loads) $\mathrm{Z}_{\mathrm{i}}$ at the $\mathrm{i}^{\text {th }}$ tyre-road contact points, can be obtained by solving Equation (1).

\subsection{Mathematical model of a three-axle truck-tractor with a three-axle semitrailer}

Additional simplifying assumptions were also adopted for the model shown in Figure 5:

- differences $u_{i}-u_{j}$ in suspension system deflections are small in comparison to the $\mathrm{l}_{\mathrm{kl}}$ dimensions specified;

- $\quad$ suspension system deflections $\mathrm{u}_{\mathrm{i}}$ are vertical (in the $\mathrm{Oz}$ direction);

- $\quad$ pitch angles of the tractor and semitrailer body solids are small (up to a few degrees);

- $\quad \mathrm{Z}_{\mathrm{i}}$ reactions are non-negative.

Equations that describe the state of static equilibrium of the truck-tractor moving rectilinearly, with a constant very low speed, have the form of equations of forces in the vertical direction $\mathrm{Oz}$, equations of the moments of forces relative to point $l$ and tangent of the pitch angle of the tractor body solid determined from deflections of the suspension systems of axles 1, 2 and 3. Similar equations that describe the state of static equilibrium of the semitrailer have the form of equations of forces acting in the vertical direction $\mathrm{Oz}$, equations of the moments of forces relative to point $\mathrm{S}$ and tangent of the pitch angle of the semitrailer body solid determined from deflections of the suspension systems of axles 4, 5 and 6 . After transformations, they take a matrix form:

$\mathbf{A Z}_{6 \times 6} \times \mathbf{Z Z}_{6 \times 1}=\mathbf{W P S Z}_{6 \times 1}$.

The non-zero elements of the $\mathbf{A Z}$ matrix are represented by a group of relations (6):

$\mathrm{AZ}(1,1)=\mathrm{AZ}(1,2)=\mathrm{AZ}(1,3)=\mathrm{AZ}(1,4)=\mathrm{AZ}(1,5)=$

$=\mathrm{AZ}(1,6)=1$,

$\mathrm{AZ}(2,1)=-\mathrm{l}_{1 \mathrm{~S}}, \mathrm{AZ}(2,2)=\mathrm{l}_{12}-\mathrm{l}_{1 \mathrm{~S}}, \mathrm{AZ}(2,3)=\mathrm{l}_{13}-\mathrm{l}_{1 \mathrm{~S}}$,

$\operatorname{AZ}(3,1)=\left(\mathrm{l}_{12}-\mathrm{l}_{13}\right) / \mathrm{k}_{1}, \mathrm{AZ}(3,2)=\mathrm{l}_{13} / \mathrm{k}_{2}, \mathrm{AZ}(3,3)=-\mathrm{l}_{12} / \mathbf{k}_{3}$,

$\mathrm{AZ}(4,2)=\mathrm{l}_{12} / \mathrm{l}_{1 \mathrm{~S}}, \mathrm{AZ}(4,3)=\mathrm{l}_{13} / \mathrm{l}_{1 \mathrm{~S}}, \mathrm{AZ}(4,4)=\mathrm{AZ}(4,5)=$

$=\mathrm{AZ}(4,6)=1$,

$\mathrm{AZ}(5,4)=\mathrm{l}_{\mathrm{S} 4}, \mathrm{AZ}(5,5)=\mathrm{l}_{\mathrm{S} 5}, \mathrm{AZ}(5,6)=\mathrm{l}_{\mathrm{S} 6}$,

$\mathrm{AZ}(6,4)=\left(\mathrm{l}_{\mathrm{S} 6}-\mathrm{l}_{\mathrm{S} 5}\right) / \mathrm{k}_{4}, \mathrm{AZ}(6,5)=-\left(\mathrm{l}_{\mathrm{S} 6}-\mathrm{l}_{\mathrm{S} 4}\right) / \mathrm{k}_{5}, \mathrm{AZ}(6,6)=$

$=\left(\mathrm{l}_{\mathrm{S} 5}-\mathrm{l}_{\mathrm{S} 4}\right) / \mathrm{k}_{6}$,

Vector ZZ has the form in Equation (7) and vector WPSZ is defined by Equation (8).

$\mathbf{Z Z}_{6 \times 1}=\operatorname{col}\left[Z_{\mathrm{i}}\right], \mathrm{i}=1,2,3,4,5,6$.

WPSZ $_{6 \times 1}=\operatorname{col}\left[\left(\mathrm{m}_{\mathrm{C}}+\mathrm{m}_{\mathrm{N}}\right) \times \mathrm{g}, \mathrm{m}_{\mathrm{C}} \times \mathrm{g} \times\left(\mathrm{l}_{1 \mathrm{C}}-\mathrm{l}_{1 \mathrm{~S}}\right), 0\right.$,

$\left.\left(\mathrm{m}_{\mathrm{C}} \times \mathrm{l}_{1 \mathrm{C}} / \mathrm{l}_{1 \mathrm{~S}}-\mathrm{m}_{\mathrm{N}}\right) \times \mathrm{g}, \mathrm{m}_{\mathrm{N}} \times \mathrm{g} \times \mathrm{l}_{\mathrm{SN}}, 0\right]$. 


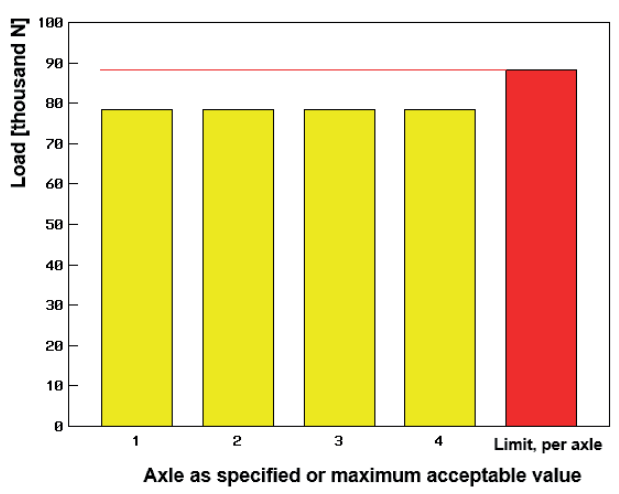

Figure 6 Calculation results obtained for the nominal data of the example four-axle motor truck in comparison to the maximum acceptable axle load values ("Limit, per axle")

The vector $\mathbf{Z Z}$ to be found (Equation (7)), representing the normal reactions (axle loads) $\mathrm{Z}_{\mathrm{i}}$ at the $\mathrm{i}^{\text {th }}$ tyre-road contact points, can be obtained by solving Equation (5)

\section{Data adopted for the example calculations}

For the motor truck calculations, the data adopted as an example represent a four-axle vehicle with an $8 \times 8$ drive system (all-wheel drive eight-wheeler) with a design similar to that of at least several truck types used in Poland, chiefly in the building industry.

The data taken for the example calculations, concerning a truck-semitrailer unit, correspond to a two-axle trucktractor with a three-axle semitrailer. The structure of such a vehicle combination is somewhat less complicated than that shown in Figure 5, but it was chosen because of being very popular in Poland. The low road gradients prevail (except for the southern regions) and transport companies usually choose truck-tractors with $4 \times 2$ drive systems (four wheels, two of them being driven), which is less expensive than the $6 \times 4$ type (six wheels, four of them being driven). The tractor-semitrailer model, as discussed in the foregoing sections, makes it possible to analyse the five-axle vehicle combinations instead of the six-axle ones, as such a model reduction would not disturb the computation algorithm. Equation (9) illustrates a modified system of denoting individual vehicle axles and tyre-road contact points, which enables the said model reduction:

$1=>1 \mathrm{c} \quad 2=>2 \mathrm{c} \quad 3=>3 \mathrm{c}$ (omitted)

$4=>1 \mathrm{n} \quad 5=>2 \mathrm{n} \quad 6=>3 \mathrm{n}$,

where: "c" and "n" means "tractor" and "semitrailer, respectively.

Point 3 (i.e. $3 \mathrm{c}$ in the new notation) would be omitted in the case of the said reduction. The mathematical model would still have the form as described by Equations (5)-(8), but the method of presenting the calculation results would be modified according to Equation (9).

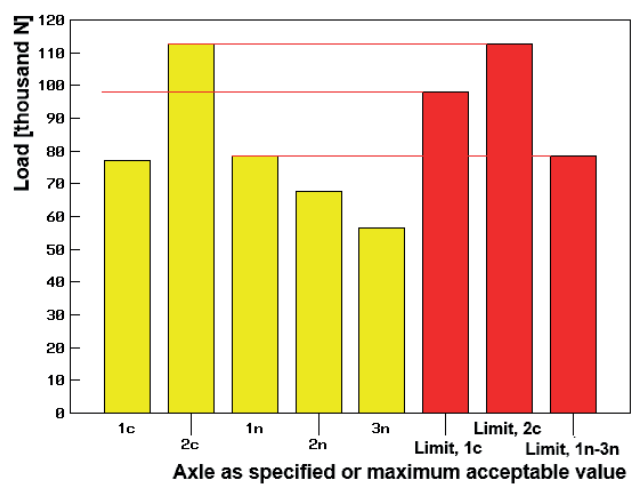

Figure 7 Calculation results obtained for the nominal data of the example two-axle truck-tractor with a three-axle semitrailer in comparison to the maximum acceptable values for the $1^{\text {st }}$ tractor axle ("Limit,1c"), $2^{\text {nd }}$ tractor axle

("Limit,2c") and a semitrailer axle ("Limit, 1n-3n")

\subsection{Nominal data of the motor truck and the tractor- semitrailer unit}

The following data were adopted for the four-axle $8 \times 8$ motor truck taken as an example: $\mathrm{m}_{\mathrm{S}}=32000 \mathrm{~kg}, \mathrm{k}_{1}=\mathrm{k}_{2}=$ $\mathrm{k}_{3}=\mathrm{k}_{4}=300000 \mathrm{~N} \cdot \mathrm{m}^{-1}, \mathrm{l}_{12}=1.7 \mathrm{~m}, \mathrm{l}_{13}=4.8 \mathrm{~m}, \mathrm{l}_{14}=6.15 \mathrm{~m}$, $\mathrm{l}_{1 \mathrm{~B}}=3.1625 \mathrm{~m}$. The maximum acceptable values are: $\mathrm{m}_{\text {Sdop }}$ $=32000 \mathrm{~kg}$ (i.e. $\mathrm{G}_{\text {Sdop }}=\mathrm{m}_{\text {Sdop }} \times \mathrm{g}=313920 \mathrm{~N}$ ) and $\mathrm{Z}_{\text {1dop }}=$ $\mathrm{Z}_{2 \text { dop }}=\mathrm{Z}_{3 \text { dop }}=\mathrm{Z}_{4 \mathrm{dop}}=9000 \mathrm{~kg} \times \mathrm{g}=88290 \mathrm{~N}$, according to the applicable normative document [1]. As it can be seen, the vehicle mass is equal to the maximum acceptable gross vehicle mass $\left(\mathrm{m}_{\mathrm{s}}=\mathrm{m}_{\text {Sdop }}\right)$. Figure 6 shows the calculation results obtained for the nominal data of the example fouraxle motor truck in comparison to the maximum acceptable values. At none of the vehicle axles, the normal reactions (axle loads) exceed the limits.

For the example truck-semitrailer unit (two-axle trucktractor with a three-axle semitrailer), the following data were adopted: $m_{\mathrm{C}}=7500 \mathrm{~kg}, \mathrm{~m}_{\mathrm{N}}=32500 \mathrm{~kg}, \mathrm{k}_{1}=$ 412000 N.m-1 $\mathrm{k}_{2}=1500000 \mathrm{~N} . \mathrm{m}^{-1}, \mathrm{k}_{4}=1340000 \mathrm{~N} . \mathrm{m}^{-1}, \mathrm{k}_{5}$ $=1340000 \mathrm{~N} \cdot \mathrm{m}^{-1}, \mathrm{k}_{6}=1340000 \mathrm{~N} \cdot \mathrm{m}^{-1}, \mathrm{l}_{12}=3.595 \mathrm{~m}, \mathrm{l}_{1 \mathrm{C}}=$ $0.567 \mathrm{~m}, \mathrm{l}_{1 \mathrm{~S}}=3.13 \mathrm{~m}, \mathrm{l}_{\mathrm{SN}}=3.849 \mathrm{~m}, \mathrm{l}_{\mathrm{S} 4}=4.89 \mathrm{~m}, \mathrm{l}_{\mathrm{S} 5}=6.20 \mathrm{~m}$, $\mathrm{l}_{\mathrm{S} 6}=7.51 \mathrm{~m}$.

The maximum acceptable values are [1]: $\mathrm{m}_{\text {Zdop }}=\left(\mathrm{m}_{\mathrm{C}}\right.$ $\left.+\mathrm{m}_{\mathrm{N}}\right)_{\text {dop }}=40000 \mathrm{~kg}$ (i.e. $\mathrm{G}_{\mathrm{Zdop}}=\mathrm{m}_{\mathrm{Zdop}} \times \mathrm{g}=392400 \mathrm{~N}$ ), $\mathrm{Z}_{1 \text { cdop }}=10000 \mathrm{~kg} \times \mathrm{g}=98100 \mathrm{~N}, \mathrm{Z}_{2 \text { cdop }}=11500 \mathrm{~kg} \times \mathrm{g}=$ $112815 \mathrm{~N}, \mathrm{Z}_{\text {1ndop }}=\mathrm{Z}_{\text {2ndop }}=\mathrm{Z}_{3 \text { ndop }}=8000 \mathrm{~kg} \times \mathrm{g}=78480 \mathrm{~N}$. The mass of the truck-semitrailer unit is equal to the maximum acceptable gross vehicle mass $\left(\mathrm{m}_{\mathrm{z}}=\mathrm{m}_{\mathrm{C}}+\mathrm{m}_{\mathrm{N}}\right.$ $=\mathrm{m}_{\mathrm{Zdop}}$ ). Figure 7 shows the calculation results obtained for the nominal data of the example two-axle truck-tractor with a three-axle semitrailer in comparison to the maximum acceptable values. At none of the vehicle axles, the normal reactions exceed the limits.

\subsection{Data of the motor truck and the tractor- semitrailer unit when overloaded}

The model of the four-axle motor truck taken as an example was overloaded by $20 \%$ and the centre of its mass 


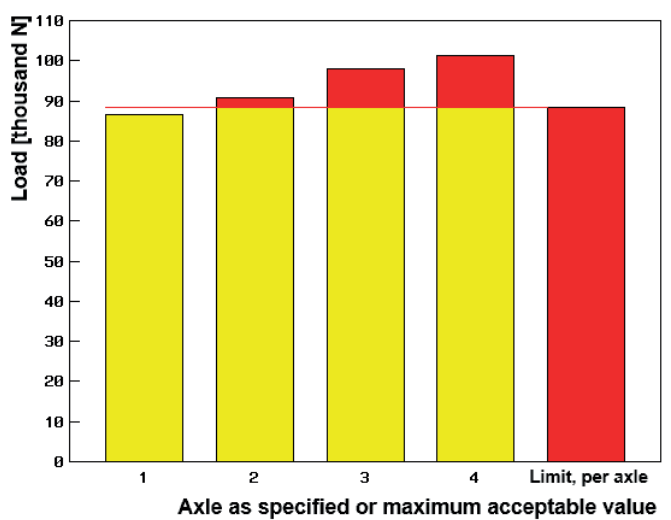

Figure 8 Calculation results obtained for the four-axle motor truck overloaded by $20 \%$, shown in comparison to the maximum acceptable axle load values ("Limit, per axle")

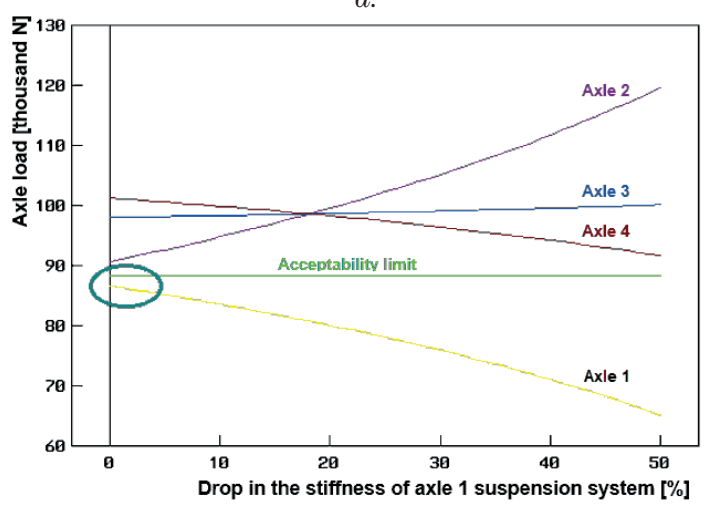

$c$

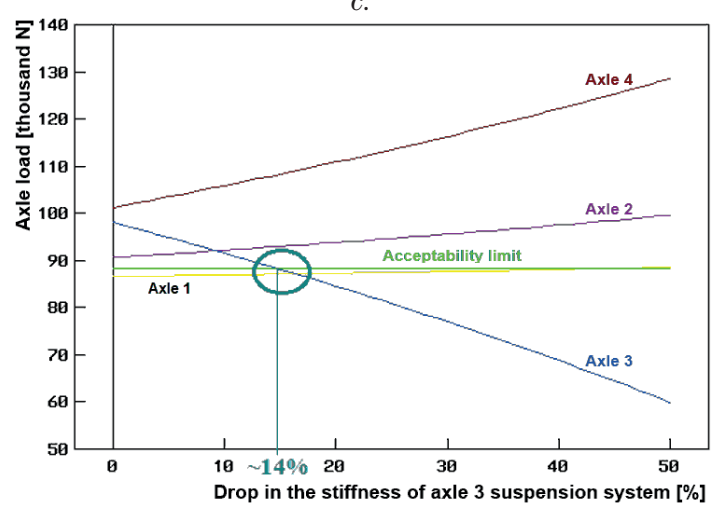

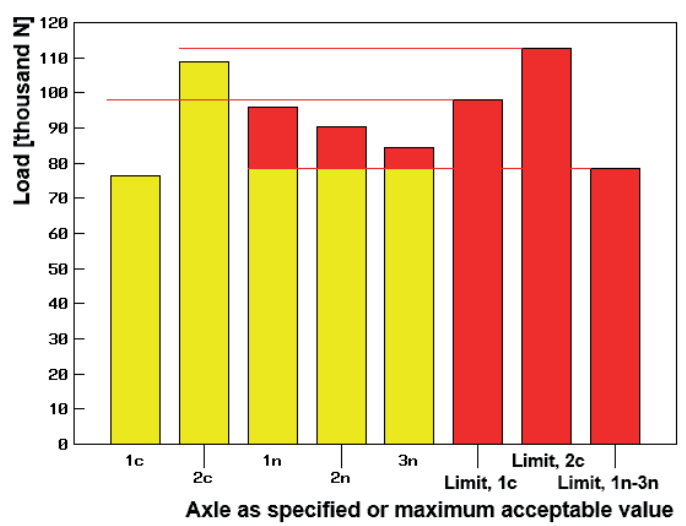

Figure 9 Calculation results obtained for the trucksemitrailer unit overloaded by 20\%, shown in comparison to the maximum acceptable values for the $1^{\text {st }}$ tractor axle ("Limit, $1 c$ "), 2 $2^{\text {nd }}$ tractor axle ("Limit, $2 c$ ") and a semitrailer axle ("Limit, 1n-3n")

$b$.

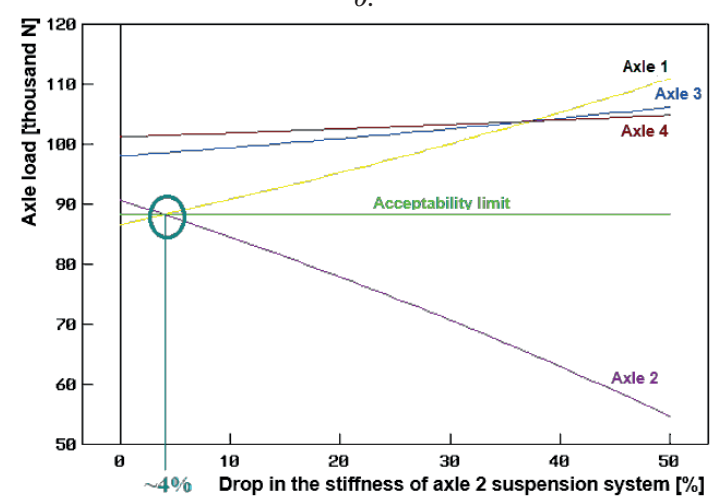

$d$

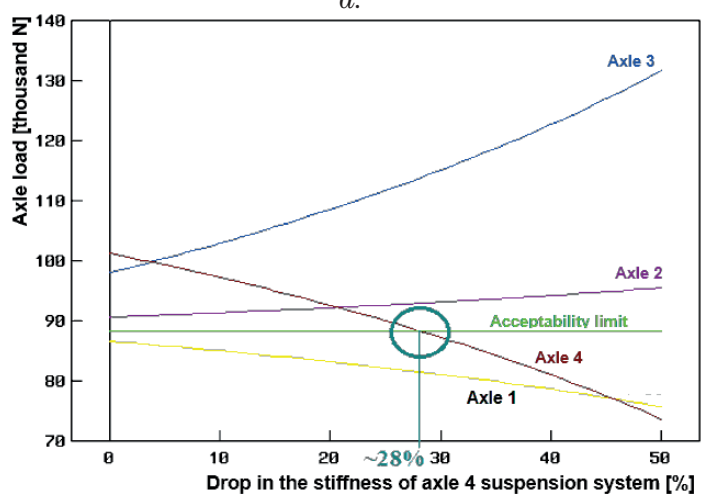

Figure 10 Motor truck. Impact of a reduction in the stiffness of suspension systems of axles 1 (a), 2 (b), 3 (c) and 4 (d) on the normal road reactions (axle loads) at pneumatic tyres of all the four vehicle axles

was shifted rearwards by $0.15 \mathrm{~m}$. Thus, the two parameters of the model were changed (cf. Figure 4 ): $\mathrm{m}_{\mathrm{S}}=38400 \mathrm{~kg}, \mathrm{l}_{1 \mathrm{~B}}$ $=3.3125 \mathrm{~m}$. Figure 8 shows the calculation results obtained for the overloaded four-axle motor truck in comparison with the maximum acceptable values. The normal reactions (axle loads) exceed the limits at axles 2, 3 and 4 .

In the model of the truck-semitrailer unit taken as an example (two-axle truck-tractor with a three-axle semitrailer), the semitrailer was overloaded by $20 \%$ and the centre of its mass was shifted rearwards by $0.5 \mathrm{~m}$. Thus, the two parameters of the model were changed (cf. Figure 5): $\mathrm{m}_{\mathrm{N}}=39000 \mathrm{~kg}, \mathrm{l}_{\mathrm{SN}}=4.349 \mathrm{~m}$. Figure 9 shows the calculation results obtained for the overloaded truck-semitrailer unit in comparison to the maximum acceptable values. The normal reactions at the semitrailer axles (1n, $2 n$ and $3 n$ ) exceed the limits.

\section{Potential capabilities of the method of deceiving when the example vehicles are weighed}

The analysed method of deceiving when the loads on individual vehicle axles are measured consists (as described above) in reducing the stiffness of specific axle's 
a.

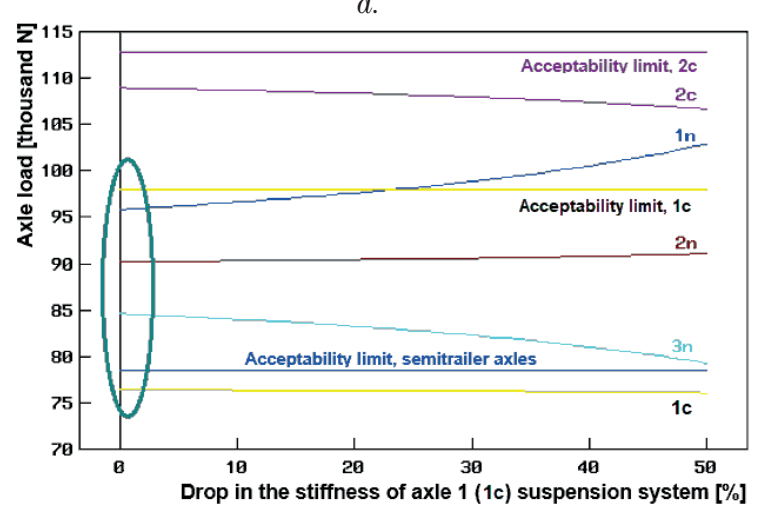

c.

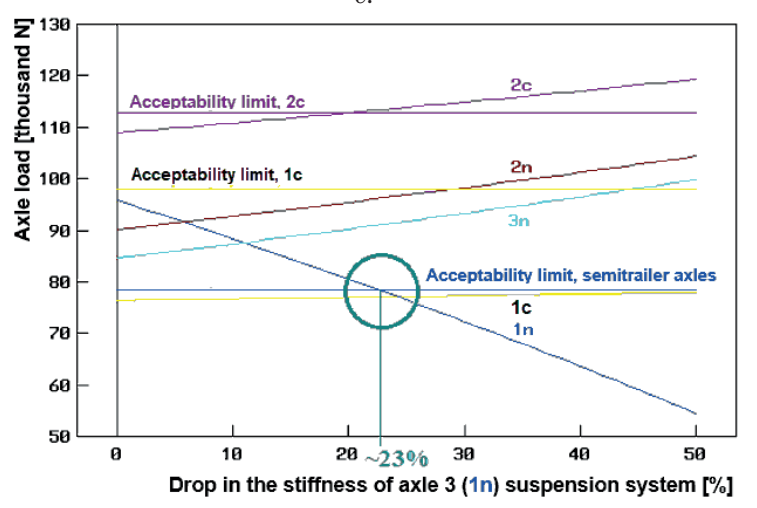

$b$.

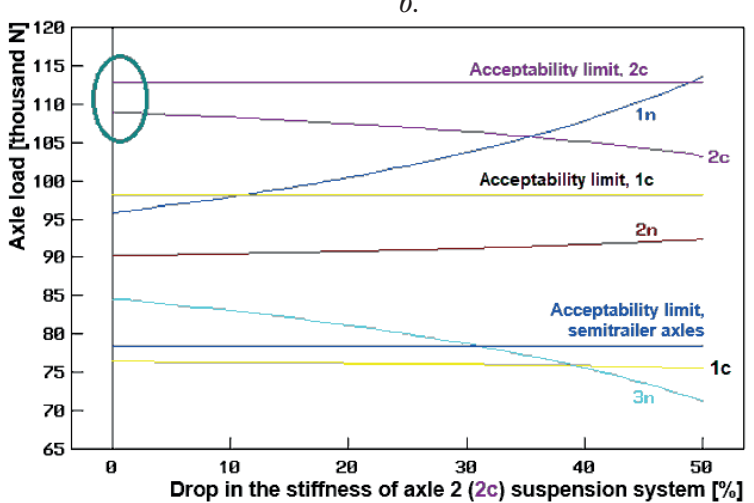

$d$.

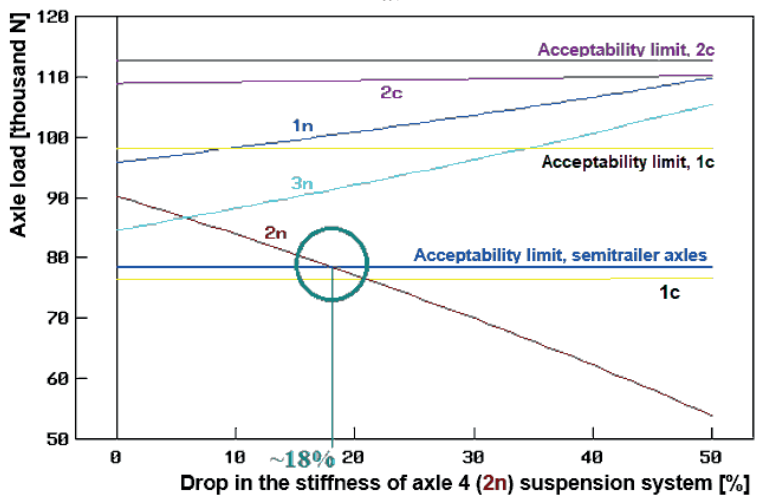

$e$.

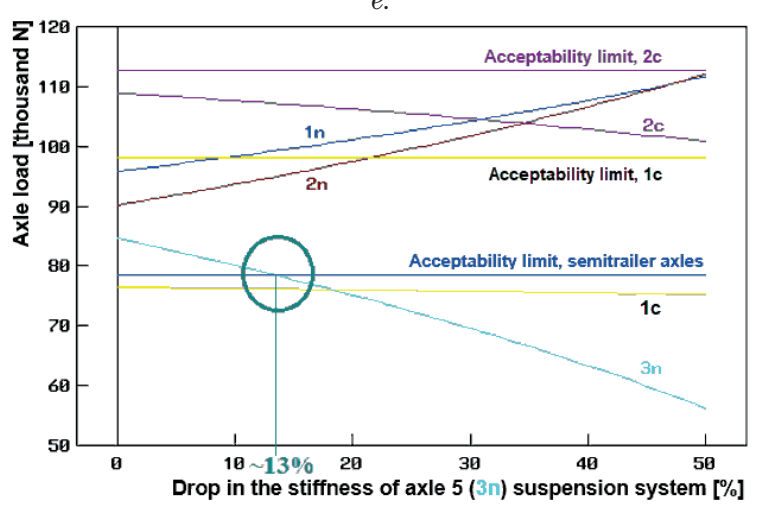

Figure 11 Tractor-semitrailer unit. Impact of a reduction in stiffness of the suspension systems of axles 1 (a), 2 (b), 3 (c) 4 (d) and 5 (e) on the normal road reactions (axle loads) at pneumatic tyres of all the five vehicle axles

suspension springs immediately before the axle load is measured. In consequence, a part of this load is taken over by the other vehicle axles, chiefly those next to the one under measurement.

\subsection{The case with overloading the example motor truck}

As mentioned before, the four-axle motor truck taken as an example for the calculations has an $8 \times 8$ drive system (it is an all-wheel drive eight-wheeler). Usually, the front axle of such vehicles is not provided with pneumatic bellows because of the confined space available, restricted by the design and mounting of vehicle's engine and steering system components. An air suspension system, whose stiffness may be varied, is provided at the $2^{\text {nd }}, 3^{\text {rd }}$ and $4^{\text {th }}$ axle or at the two rearmost axles. Figure 10 shows impact of a reduction in stiffness of the suspension systems of individual vehicle axles on the normal road reactions (axle loads) at pneumatic tyres of all the four axles. The $1^{\text {st }}$ axle (Figure 10a) is not overloaded. Should, however, a reduction in the stiffness of the suspension system of this axle be possible then the normal road reaction (axle load) would decline with the said drop in the stiffness of this suspension system. The load on the $4^{\text {th }}$ axle would also decrease, at the expense of a growth in the loads on axles 2 and 3. Since the front axles of vehicles of this type are not usually provided with pneumatic bellows, the interference in the front axle suspension system will not be discussed here. The $2^{\text {nd }}$ axle (Figure $10 \mathrm{~b}$ ) is overloaded. A decline in the stiffness of its suspension system causes a drop in the normal road reaction (axle load); namely, if this stiffness declines by as little as about $4 \%$, the axle load drops to the 
acceptability limit. A decrease in this load is accompanied by growths in the loads on the other vehicle axles. The $3^{\text {rd }}$ axle (Figure 10c) is overloaded, too. Again, a decline in the stiffness of its suspension system causes a drop in the normal road reaction (axle load). Here, a load drop to the acceptability limit is achieved when the suspension stiffness is reduced by about $14 \%$. Consistently, growths are observed in the loads on the other axles, with the lowest value of this growth being observed at the $1^{\text {st }}$ axle. Overloading also takes place at the $4^{\text {th }}$ axle (Figure $10 \mathrm{~d}$ ). This overload also declines with a drop in the stiffness of the suspension system of this axle, but this stiffness must be reduced by about $28 \%$ for the acceptability limit of the axle load to be achieved. In this case, the load on the $1^{\text {st }}$ axle declines as well, with the loads on axles 2 and 3 increasing at the same time. Results shown in Figure 10 indicate a high potential of the presented method of interfering in measurements of normal road reactions, i.e. in determination of the loads on individual vehicle axles.

\subsection{The case with overloading the example tractor- semitrailer unit}

The model of a tractor-semitrailer unit, taken as an example for calculations, represents a combination of a two-axle truck-tractor having a $4 \times 2$ drive system (four wheels, two of them being driven) with a three-axle semitrailer. Here, Equation (9) should be recalled, which was adopted when the six-axle model of Figure 5 was replaced by a five-axle one. As in the motor truck case, the truck-tractor's front axle is not provided with pneumatic bellows because of confined space available, restricted by the design and mounting of vehicle's engine and steering system components. An air suspension system, whose stiffness may be varied, is sometimes provided at the $2^{\text {nd }}$ tractor's axle only. On the other hand, such systems very often occur at semitrailer axles. Figure 11 shows the impact of a reduction in the stiffness of suspension systems of individual vehicle axles on the normal road reactions (axle loads) at pneumatic tyres of all the five axles. The $1^{\text {st }}$ axle of the tractor (Figure 11a) is not overloaded. Should, however, a reduction in the stiffness of the suspension system of this axle be possible, then the normal road reaction (axle load) would decline (at a very low rate, hardly noticeable) with the said drop in the stiffness of this suspension system. A decrease in the load would also take place at the $2^{\text {nd }}$ axle of the tractor and the $3^{\text {rd }}$ (rearmost) axle of the semitrailer. Conversely, the load on the other semitrailer axles would increase (with the rate of this growth being higher at the $1^{\text {st }}$ axle). As mentioned above, truck-tractors' front axles are not usually provided with pneumatic bellows; therefore, the interference in the suspension system of this axle will not be discussed here. The $2^{\text {nd }}$ axle of the tractor (Figure $11 b)$ is not overloaded, either. With declining stiffness of its suspension system, the normal road reaction (axle load) decreases and so does the load on the $3^{\text {rd }}$ axle of the semitrailer and the $1^{\text {st }}$ axle of the tractor (although at an insignificant rate in the latter case). This is accompanied by an increase (slight in this case) in the loads of semitrailer axles 1 and 2 .

The $3^{\text {rd }}$ axle of the tractor-semitrailer unit, i.e. the $1^{\text {st }}$ semitrailer axle (Figure 11c) is markedly overloaded. With a decline in the stiffness of its suspension system, the load of this axle decreases, as well. The load drops to its acceptability limit when the suspension stiffness is reduced by about $23 \%$. This process is accompanied by an increase in the load on the other vehicle axles, especially on the $2^{\text {nd }}$ axle of the tractor and on the $2^{\text {nd }}$ and $3^{\text {rd }}$ semitrailer axle. The $2^{\text {nd }}$ semitrailer axle (Figure 11d) is overloaded, too. A reduction in the stiffness of its suspension system results in a decline in the axle load, with the load acceptability limit being achieved when the stiffness is lowered by about $18 \%$. This takes place at a simultaneous growth in the load on other vehicle axles, especially on the $1^{\text {st }}$ and $3^{\text {rd }}$ semitrailer axle. The $3^{\text {rd }}$ semitrailer axle (Figure 11e) is overloaded and, as it is in the other cases, a reduction in its suspension stiffness causes a drop in its load, which crosses the acceptability limit when the stiffness decreases by about 13\%. In such a situation, the load drops on the $2^{\text {nd }}$ tractor axle and slightly declines on the $1^{\text {st }}$ tractor axle, while the loads increase on the $1^{\text {st }}$ and $2^{\text {nd }}$ semitrailer axles. Results shown in Figure 11 indicate a considerable potential of the presented method of interfering in the measurements of normal road reactions, i.e. in determination of the loads on the axles of a vehicle combination consisting of a two-axle truck-tractor with a three-axle semitrailer. This particularly applies to the semitrailer axles.

\section{Results of weighing the example vehicles while the presented methods of interfering in the stiffness of vehicle suspension systems are employed}

The method of deceiving when the loads on individual vehicle axles are measured, described in Section 7, was verified for the example data adopted here to represent a four-axle motor truck and a two-axle truck-tractor with a three-axle semitrailer. Due to the vehicle design constraints (air suspension systems are mainly provided at the $2^{\text {nd }}, 3^{\text {rd }}$ and $4^{\text {th }}$ axle or at the two rearmost axles of the four-axle motor trucks and at semitrailer axles), hypothetical interference (of persons wanting to affect the weighing results) was only considered for the $2^{\text {nd }}, 3^{\text {rd }}$ and $4^{\text {th }}$ axle of the motor truck and for the three semitrailer axles in the tractor-semitrailer unit. This means a lower number of the vehicle axles where the suspension stiffness could be altered. An assumption was made that the suspension stiffness was reduced by $50 \%$.

Figure 12 shows calculation results obtained for overloading of the example four-axle motor truck. They include loads on individual vehicle axles, actual vehicle weight, maximum acceptable value of the vehicle load and result of a measurement with the said interference in 


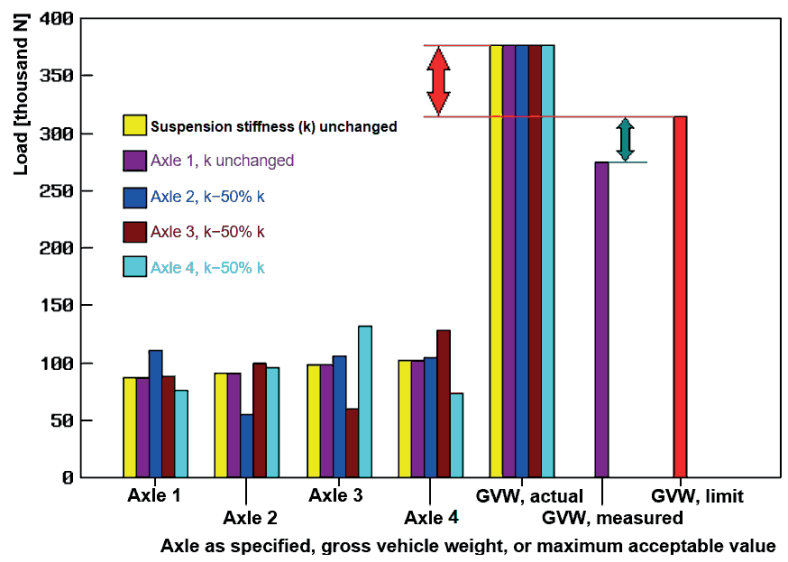

Figure 12 Calculation results for the example four-axle motor truck overloaded by 20\%, compared to the maximum acceptable load values. Loads on individual axles ("Axle 1", "Axle 2", "Axle 3", "Axle 4"), actual gross vehicle weight ("GVW, actual"), gross vehicle weight limit ("GVW, limit") and gross vehicle weight measurement result obtained with changing the suspension stiffness at axle 2, 3 and 4 as described ("GVW, measured")

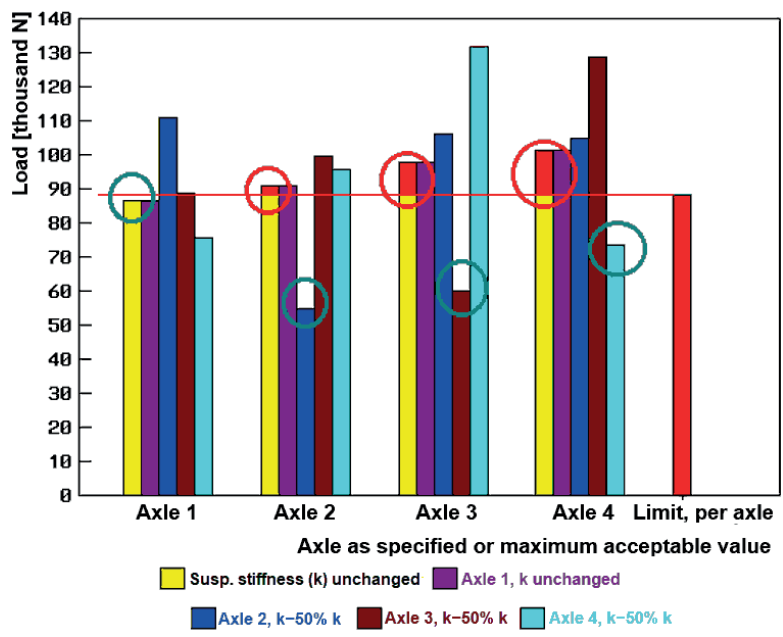

Figure 13 Calculation results for the example four-axle motor truck overloaded by 20\%, compared to the maximum acceptable load values. Loads on individual axles ("Axle 1", "Axle 2", "Axle 3", "Axle 4") and maximum acceptable axle load ("Limit, per axle"). The red rings indicate the state of overloading and the green rings indicate either the state that the acceptability limit is actually not exceeded (axle 1) or the effect of changing the suspension stiffness (axles 2, 3 and 4)

the form of altering the stiffness of suspension systems of axles 2, 3 and 4. The vehicle weight remained unchanged during the measurements. The vehicle weight considerably exceeded the acceptability limit, which has been indicated by a double red arrow. However, the sum of results of measurements of individual vehicle axle loads was lower than the acceptability limit and this in turn has been indicated by a double green arrow. This means that the

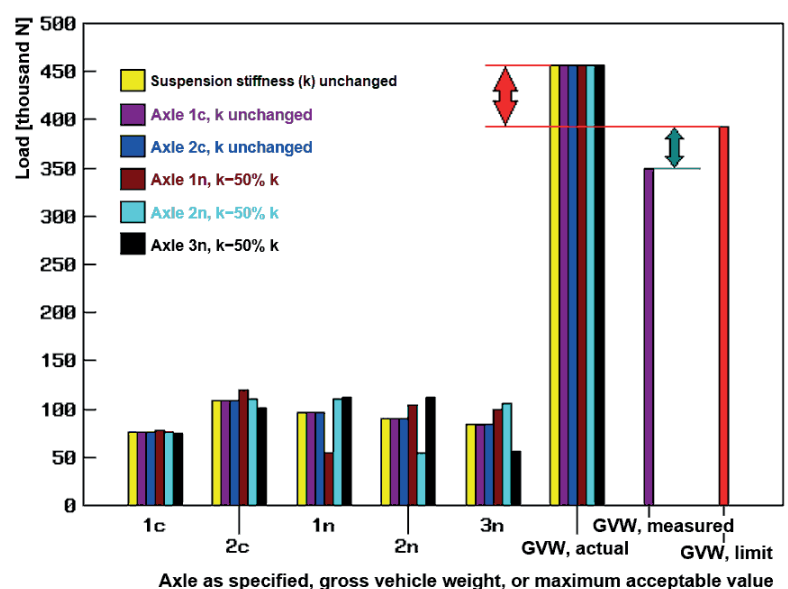

Figure 14 Calculation results for the example tractorsemitrailer unit where the semitrailer was overloaded by $20 \%$, compared to the maximum acceptable load values. Loads on individual axles (" $1 c$ ", "2c", "1n", "2n", "3n"), actual gross weight of the vehicle combination (" $G V W$, actual"), maximum acceptable gross weight of the vehicle combination ("GVW, limit") and gross weight of the vehicle combination as measured with changing the suspension stiffness at semitrailer axles $1 n, 2 n$ and $3 n$ as described ("GVW, measured")

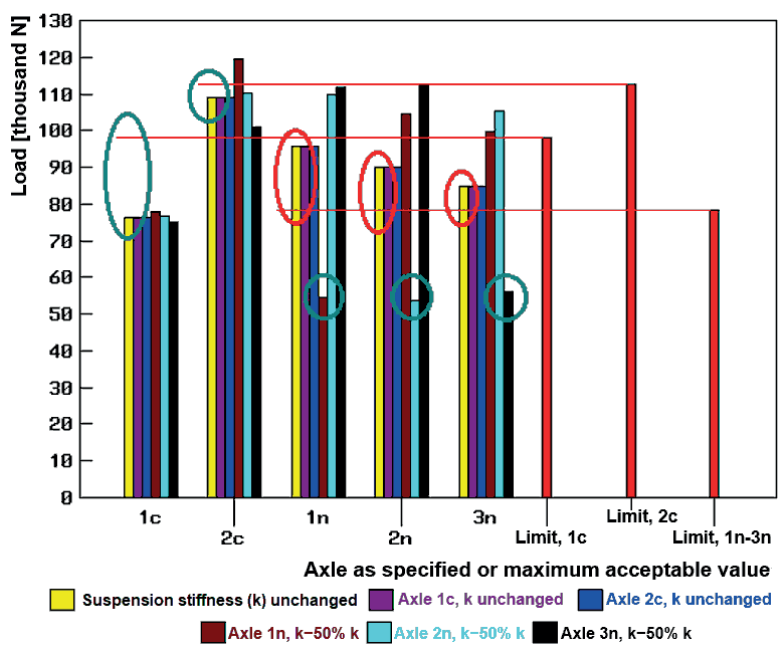

Figure 15 Calculation results for the example tractorsemitrailer unit where the semitrailer was overloaded by $20 \%$, compared to the maximum acceptable load values. Loads on individual axles ("1c", "2c", "1n", "2n", "3n"), maximum acceptable values for the $1^{\text {st }}$ tractor axle ("Limit, 1c"), $2^{\text {nd }}$ tractor axle ("Limit, 2c") and a semitrailer axle ("Limit, $1 n$-3n"). The red rings indicate the state of overloading and the green rings indicate either the state that the acceptability limit was actually not exceeded (tractor axles 1c and 2c) or the effect of changing the suspension stiffness (semitrailer axles $1 n, 2 n$ and $3 n$ )

effect of seemingly lower gross vehicle weight, translated into the gross vehicle mass subject to assessment, was achieved.

Figure 13 shows the same results but rearranged to focus on the loads on individual axles compared to the applicable acceptability limits. The red rings indicate the state of overloading without any interference in the suspension stiffness. The green rings indicate either the 
state that the acceptability limit was actually not exceeded (axle 1), or the effect of changing the suspension stiffness (axles 2, 3 and 4), where the load measured (scale readout) was lower than the applicable acceptability limit. In the example shown, the said interference in the stiffness of vehicle axle suspensions may be assessed as successful. For the example motor truck, the measurement results presented in Figures 12 and 13 fraudulently show that the total vehicle load and the loads on individual vehicle axles did not exceed the acceptability limits.

Figure 14 shows calculation results obtained for overloading of the example tractor-semitrailer unit. They include loads on individual tractor and semitrailer axles, actual weight of the complete vehicle combination, maximum acceptable values of the vehicle load and result of a measurement with the said interference in the form of changing the stiffness of suspension systems of the semitrailer axles (1n, $2 n$ and $3 n$ ). The weight of the vehicle combination remained unchanged during the measurements. The vehicle weight considerably exceeded the acceptability limit, which has been indicated by a double red arrow. However, the sum of results of measurements of individual vehicle axle loads was lower than the acceptability limit and this in turn has been indicated by a double green arrow. This means that the effect of seemingly lower gross vehicle weight, translated into the gross vehicle mass subject to assessment, was achieved.

Figure 15 shows the same results but rearranged to focus on the loads on individual axles compared to the applicable acceptability limits. The red rings indicate the state of overloading without any interference in the suspension stiffness. The green rings indicate either the state that the acceptability limit was actually not exceeded (truck-tractor axles 1c and 2c), or the effect of changing the suspension stiffness (semitrailer axles $1 n, 2 n$ and $3 n$ ), where the load measured (scale readout) was lower than the applicable acceptability limit. For the tractor semitrailer unit taken as an example, the said interference in the stiffness of suspensions of the semitrailer axles specified, may be assessed as successful. The measurement results presented in Figures 14 and 15 fraudulently show that the total vehicle load and the loads on individual vehicle axles did not exceed the acceptability limits.

\section{Closing conclusions}

The possibility of deceit while a vehicle is weighed in motion with a very low speed has been discussed. Two authorial linear vehicle models were used in the analysis. Calculation results obtained with using a dedicated author's own simulation program ZL_WIM19 have been presented. For the calculations, data representing an example fouraxle motor truck and a five-axle tractor-semitrailer unit were assumed.

The calculations show that a deceit as mentioned above is feasible. A conclusion may be formulated that a trick described herein, i.e. alteration of the suspension stiffness at predefined axles of the example four-axle motor truck, may successfully distort the vehicle weighing results, which would then fraudulently show that the axle loads and gross weight of the vehicle do not exceed the acceptable limits. For the example truck-semitrailer unit, the deceit under consideration has also been found possible and the weighing results may fraudulently show that the axle loads and gross weight of the vehicle are within the acceptable limits.

The calculation results quoted in the study should be mainly considered as qualitative only; nevertheless, their error may be expected not to be very big for the assumptions adopted as regards the example vehicles and measurement conditions.

\section{References}

[1] Announcement of the Minister of Infrastructure and Building Industry of 27 October 2016 on the publishing of a consolidated text of the Regulation of the Minister of Infrastructure and Building Industry on the technical requirements for vehicles and their necessary equipment. Warszawa: Journal of Laws of the Republic of Poland of 15 December 2016, item 2022.

[2] BURNOS, P. Weighing of road vehicles in motion. Part 1, Impact of overloaded vehicles on the pavement / Wazenie pojazdow samochodowych w ruchu. Czesc 1: Oddzialywanie pojazdow przeciazonych na nawierzchnie (in Polish). Drogownictwo. 2014, 6, p. 192-196. ISSN 0012-6357.

[3] ZIOBRO, K. (Member of Parliament of the Republic of Poland). Parliamentary Question No 34607 to the Minister of Infrastructure and Development on the poor condition of road infrastructure caused by excessive vehicle loading [online] [accessed 2019-09-09]. Lancut, 2015. Available from: http://www.sejm.gov.pl/sejm7.nsf/InterpelacjaTresc. xsp?key=6BDF5971

[4] MARCZAK, P. The impact of heavy vehicles on the condition of local roads / Wplyw ciezkich pojazdow na stan drog lokalnych (in Polish). Warszawa: Analyses and Research Unit, Analyses, Documentation and Correspondence Office, Chancellery of the Senate of the Republic of Poland, 2009.

[5] FHA - Federal Highway Administration. LTBP Program's literature review on Weigh-in-Motion Systems. Publication No FHWA-HRT-160024. Georgetown Pike, 2016. 
[6] BURNOS, P. Weighing of road vehicles in motion. Part 2., Types and characteristics Weigh in Motion systems / Wazenie pojazdow samochodowych w ruchu. Czesc 2: Rodzaje i charakterystyka systemow Weigh in Motion (WIM) (in Polish). Drogownictwo. 2014, 7-8, p. 240-244. ISSN 0012-6357.

[7] JACOB, B., O'BRIEN, E. J. WAVE - a European research project on Weigh-in-Motion. In: National Traffic Data Acquisition Conference NATDAQ '96: proceedings [online] [accessed 2019-06-13]. 1996. Available from: http://ntl.bts. gov/lib/jpodocs/proceedn/443.pdf

[8] JACOB, B., O'BRIEN, E. Weigh-in-Motion: recent developments in Europe. 4th International Conference on WIM: proceedings. 2005.

[9] LYNDON, M., TAYLOR, S. E., ROBINSON, D., MUFTI, A., O'BRIEN, E. J. Recent developments in bridge weigh in motion (B-WIM). Journal of Civil Structural Health Monitoring [online]. 2016, 6(1), p. 69-81. ISSN 2190-5452, eISSN 2190-5479. Available from: https://doi.org/10.1007/s13349-015-0119-6

[10] Mettler Toledo. Industrial weighing and measuring. Vehicle weighing. Newsletter 13. Nanikon, Switzerland: MettlerToledo GmbH Industrial Division, 2017.

[11] Truck scales / Wagi samochodowe (in Polish) - Wagotechnika [online] [accessed 2019-06-15]. Available from: http://www.wagotechnika.pl/katalog/produkty/wagi-przemyslowe/wagi-samochodowe?gclid=Cj0KCQiAw5_ fBRCSARIsAGodhk9f02 Pn3ikHaTkbTYGx3Ln_WN4uZiPYSL_Vs5wIdzYkq7X4lpygIPYaAmKyEALw_wcB

[12] Truck scales. Electronic truck scales. - Factory Wag Kalisto [online] [accessed 2018-11-11]. Available from: http://www.kalisto.pl/wagi-samochodowe/

[13] Company's publicity materials - GS Software [online] [accessed 2018-11-11]. Available from: www.gs-software.pl

[14] Truck scales: characteristics and specifications - Herkules [online] [accessed 2018-11-11]. Available from: http://herkules-wagi.pl/wagi-samochodowe/

[15] All-embracing weighing systems / Kompleksowe systemy wazace (in Polish) - MASA Zenon Kolankowski [online] [accessed 2019-06-14]. Available from: www.masa.com.pl

[16] Truck scales. Weighing platforms for road vehicles / Wagi samochodowe dla pojazdow drogowych. Pomosty wagowe dla pojazdow drogowych (in Polish) - Mettler Toledo [online] [accessed 2018-11-11]. Available from: https://www.mt.com/pl/pl/home/products/Transport_and_Logistics_Solutions/Truck_Scales/road_bridge.html

[17] Weighbridge DFT-E - Schenck [online] [accessed 2018-11-11]. Available from: https://www.schenckprocess.com/pl/ products/truck-pit-scale-dft-e

[18] Truck scales / Wagi samochodowe (in Polish) - Uniwag [online] [accessed 2018-11-11]. Available from: https://uniwag. pl/Oferta/wagi_samochodowe_-_elektroniczne/1/

[19] Innovative truck scales - a way to a success / Innowacyjne wagi samochodowe - droga do sukcesu (in Polish) - Wagen-Mont Pawel Montowski [online] [accessed 2018-11-11]. Available from: http://www.wagen-mont. pl/?gclid=Cj0KCQiAw5_fBRCSARIsAGodhk_D-TfXj365g5DIindF_-PTNMvIxJLI0FsE3OpKsx6mwI44hzyGAJ8aAq 38EALw_wcB

[20] Truck scale INPT011 - Aliexpress [online] [accessed 2018-11-11]. Available from: https://pl.aliexpress.com/item/20tcapacity-wireless-dynamic-portable-vehicle-axle-weighing-truck-scale-weigh-bridge-weight-pads-weighingscale/32702594284.html

[21] Portable truck scales. WWS system - Dini Argeo [online] [accessed 2018-11-11]. Available from: http://www.ewp.com. $\mathrm{pl}$ /wagi-samochodowe/wagi-przenosne

[22] DANIEK, S. System of vehicle preselection by weight on roads administered by ZDW Lodz. Intelligent system of vehicle preselection by weight on roads administered by ZDW Lodz as an example of the "SMART" integrated system of road traffic management and meteorological protection / System preselekcji wagowej pojazdow $w$ ZDW Lodz. Inteligentny system preselekcji wagowej pojazdow na drogach ZDW Lodz jako przyklad zintegrowanego systemu oslony meteorologicznej i zarzadzania ruchem „SMART” (in Polish). Krakow: TRAX elektronik Sp. J., 2010.

[23] WIM PRO 2.0 system - APM PRO sp. z o.o. [online] [accessed 2019-06-14]. Available from: https://apm.pl/systemy/ wim/

[24] Electronic catalogues - DTR VMS Italy [online] [accessed 2019-06-17]. Available from: https://www.dtrvms.it/en/ market-and-products/trucks

[25] Engineering Manual and Design Guide 2013 - Firestone [online] [accessed 2019-03-08]. Available from: www.firestoneip.com https://www.firestoneip.com/content/dam/fsip/pdfs/airide/commercial-air-spring-catalogEU-east.pdf

[26] Design manuals - Saf-Holland Group [online] [accessed 2019-03-08]. Available from: https://corporate.safholland.com/ en/company/about-us/history

[27] LOZIA, Z. Vehicle dynamics model as road-pavement load generator. Engineering Transactions. 2000, 48(3), p. 243-259. ISBN 0867-888X.

[28] LOZIA, Z. Analysis of biaxial car motion based upon dynamic models / Analiza ruchu samochodu dwuosiowego na tle modelowania jego dynamiki (in Polish). A monograph. Warszawa: Prace Naukowe Politechniki Warszawskiej, 1998. ISSN 1230-9265. 
[29] LOZIA, Z. Examples of authorial models for the simulation of motor vehicle motion and dynamics. Proceedings of the Institute of Vehicles. 2015, 104(4), p. 9-27. 1642-347X.

[30] ARCZYNSKI, S. Mechanics of motion of the motor vehicle / Mechanika ruchu samochodu (in Polish). Warszawa: WNT, 1993. ISBN 83-204-1488-1.

[31] KAMINSKI, E., POKORSKI, J. Automobile theory. Dynamics of suspension systems and powertrains of motor vehicles / Teoria samochodu. Dynamika zawieszen i ukladow napedowych pojazdow samochodowych (in Polish). Warszawa: WKL, 1983. ISBN 832060348X. 